\title{
HEPATITIS B, C AND HIV CO-INFECTIONS SEROPREVALENCE IN A NORTHEAST BRAZILIAN CENTER
}

\author{
Lara Gurgel Fernandes TÁVORA', 2 , Elodie Bomfim HYPPOLITO², \\ José Napoleão Monte da CRUZ', Nyvia Maria Barroso PORTELA', \\ Samuel Montenegro PEREIRA ${ }^{1}$ and Camila Monteiro VERAS ${ }^{1}$
}

\begin{abstract}
Context - The occurrence of HIV and hepatitis B (HBV) and C (HCV) virus associations is of great concern since co-infected patients respond poorly to antiviral treatment and usually progress to chronic and more complicated hepatic disease. In Brazil, these co-infections prevalence is not well known since published data are few and sometimes demonstrate conflicting results. Also, a significant number of co-infected individuals are HBV/HCV asymptomatic carriers, leading to under notification. Objectives - The present study aimed to determine the prevalence of the HBV and HCV infection in a recently diagnosed HIV population in the state of Ceará/Brazil. Methods - Retrospective cohort, with >18yo patients diagnosed HIV+ from 2008-2010. First year medical attention information was collected. Results - A total of $1.291 \mathrm{HIV}+$ patients were included. HBV serologies were collected in $52 \%(23 \%$ had previous hepatitis B, 3.7\% were co-infected) and $\mathrm{HCV}$ in $25.4 \%$ ( $1.5 \%$ had previous hepatitis C, $5.4 \%$ co-infection). The majority of HBV/HIV patients referred multiple sexual partners/year, 28\% homosexualism and 20\% bisexualism. In the HCV/HIV group 38.8\% individuals had > one sexual partner/year and 22.2\% used intravenous drugs. Conclusion - The study reinforce the need for better training healthcare workers and providing laboratory support for a prompt hepatitis diagnosis and adequate medical management to avoid complications and decrease viral spread.
\end{abstract}

HEADINGS - AIDS-Related Opportunistic Infections. Hepatitis B virus. Hepatitis C. Chronic hepatitis.

\section{INTRODUCTION}

In Brazil, since 1996, the HIV/AIDS program delivers antiretroviral therapy to eligible individuals based on a national guideline ${ }^{(3)}$. This current practice has caused a significant decrease on AIDS related mortality, which leaded to prolonged survival expectancy and, as a consequence, increased vulnerability to other infections. The HIV, hepatitis B (HBV) and C (HCV) viruses have coincident mechanisms of transmission. In fact, concomitant infections involving these associations became quite common nowadays. The hepatitis viruses (B and C)/HIV co-infections are major clinical problems, since these patients usually respond poorly to antiviral treatment, being more susceptible to progress to chronic and more complicated hepatic disease $^{(1,12)}$. Therefore, the knowledge of Hepatitis B/C and HIV co-infection status becomes an important issue in order to determine adequate strategies for prevention and treatment of this specific population.

In Brazil, hepatitis B and C seroprevalence varies according to both geographic and population risk factors. In Brazilian North-Northeast regions, $0.2 \%$ to $0.6 \%$ of the individuals with ages ranging from 13 to 69 years is $\mathrm{HBsAg}$ positive ${ }^{(10)}$. This prevalence is particularly elevated in high risk populations, such as drug addicted individuals $(27,3 \%)^{(8)}$. An overall HCV prevalence of $2.5 \%$ to $10 \%$ has been estimated by the WHO in Brazil( ${ }^{(18)}$. In contrast, some national studies results point toward a lower prevalence, at least in the Northeast region: $0.5 \%-5 \% 0^{(2,9)}$.

In Brazil, hepatitis viruses (B and C) and HIV co-infections prevalence is not well known since published data are few and sometimes demonstrate conflicting results. Also a significant number of co-

\footnotetext{
Declared conflict of interest of all authors: none

${ }^{1}$ Universidade de Fortaleza (UNIFOR), Fortaleza, CE, Brasil: ${ }^{2}$ Hospital São José; Fortaleza, CE, Brasil ${ }^{3}$ Laboratório Central de Saúde Pública (LACEN), Fortaleza, CE, Brasil. Research performed at: Hospital São José de Doenças Infecciosas. Ambulatório de HIV/AIDS e Hepatites virais.

Correspondence: Lara Gurgel Fernandes Távora. Av. Engenheiro Santana Jr. 2947, ap. 1402 - Cocó - 60192-205 - Fotaleza, CE, Brasil. E-mail: laratavora@gmail.com
} 
infected individuals are asymptomatic carriers of hepatitis viruses, which leads to a delayed diagnosis and under notification. In brazilian studies, HBV/HIV prevalence ranges from $2.8 \%$ to $4.8 \%$, whereas $\mathrm{HCV} / \mathrm{HIV}$ co-infection rates vary from $4.4 \%$ to $36.2 \%(6,14,15,17,19)$.

The present study aimed to determine the prevalence of the HBV and HCV infection in a recently diagnosed HIV population in the state of Ceará - Brazil. The authors also investigate other relevant epidemiological aspects related to this condition.

\section{METHODS}

This retrospective cohort included adult ( $>18$ years old) patients, diagnosed HIV positives from 2008-2010. Medical records were reviewed and data on the first year of regular follow-up visits were collected. All patients attended medical treatment at Hospital São José of Infectious Diseases, a reference in infectious disease care in the state of Ceará, Brazil. Demographic data, the occurrence of risk factors for HIV, HBV and $\mathrm{HCV}$ infection and serologic results from the first year of medical attention were collected. Definitive HIV diagnosis was considered with the presence of, at least, two positive serologic tests, with one of them being a specific method (Western blot, Imunoblot or indirect immunofluorescence). Patients were considered HBV carrier only if they were HBsAG positive. The occurrence of a positive total anti-HBc with a negative HBsAg was considered previous hepatitis B infection. Positivity of both anti-HCV and RNA-PCR for HCV was needed for the diagnosis of $\mathrm{HCV}$ infection. A positive anti-HCV with negative HCV RNA-PCR was considered previous contact with HCV. The study was approved by the hospital Ethical Research Committee (document $n^{\circ}$ 007/2010). Epi Info 3.5.3 version was used for statistical analysis.

\section{RESULTS}

A total of 1,291 HIV positive patients were followed. In the first year, $671(52 \%)$ of them collected HBV serologic tests: $23 \%$ (154 patients) had previous hepatitis B and 3.7\% (25 patients) were co-infected. Only $329(25.4 \%)$ had undergone serologic tests for $\mathrm{HCV}: 1.5 \%$ (5 patients) had previous hepatitis $\mathrm{C}$ and $5.4 \%$ (18 patients) were co-infected. Table 1 shows descriptive data.

TABLE 1. Hepatitis B, C and HIV co-infected patients in Ceará-Brazil, 2008-2010: descriptive data

\begin{tabular}{|c|c|c|}
\hline Variables & HIV/HBV co-infected & HIV/HCV co-infected \\
\hline $\begin{array}{l}\text { Gender }(\%): \\
\text { Male } \\
\text { Female }\end{array}$ & $\begin{array}{c}23(92) \\
02(8)\end{array}$ & $\begin{array}{l}14(77.8) \\
04(22.2)\end{array}$ \\
\hline Mean age in years (standard deviation) & $37.4(+/-9.1)$ & $39.7(+/-7.7)$ \\
\hline $\begin{array}{l}\text { Educational degree }(\%) \text { : } \\
\text { Incomplete second degree } \\
\text { Complete second degree } \\
\text { University degree } \\
\text { Ignored }\end{array}$ & $\begin{array}{l}06(24) \\
05(20) \\
03(12) \\
11(44)\end{array}$ & $\begin{array}{l}06(33.4) \\
04(22.2) \\
02(11.1) \\
06(33.3)\end{array}$ \\
\hline $\begin{array}{l}\text { Sexual practice }(\%) \text { : } \\
\text { Bisexualism } \\
\text { Heterosexualism } \\
\text { Homosexualism } \\
\text { Ignored }\end{array}$ & $\begin{array}{l}05(20) \\
06(24) \\
07(28) \\
07(28)\end{array}$ & $\begin{array}{c}05(27.8) \\
08(44.4) \\
- \\
05(27.8)\end{array}$ \\
\hline $\begin{array}{l}\mathrm{N}^{0} \text { of sexual partners/year }(\%) \text { : } \\
>3 \\
2-3 \\
\text { Monogamic } \\
\text { Ignored }\end{array}$ & $\begin{array}{c}10(40) \\
03(12) \\
- \\
12(48)\end{array}$ & $\begin{array}{c}05(27.7) \\
02(11.1) \\
02(11.1) \\
09(50)\end{array}$ \\
\hline $\begin{array}{l}\text { IV drug use }(\%) \text { : } \\
\text { Yes } \\
\text { No } \\
\text { Ignored }\end{array}$ & $\begin{array}{c}02(9.1) \\
15(68.2) \\
05(22.7)\end{array}$ & $\begin{array}{l}04(22.2) \\
12(66.7) \\
02(11.1)\end{array}$ \\
\hline $\begin{array}{l}\text { Alcohol use }(\%) \text { : } \\
\text { Yes } \\
\text { No } \\
\text { Ignored }\end{array}$ & $\begin{array}{l}09(36) \\
06(24) \\
10(40)\end{array}$ & $\begin{array}{l}08(44.4) \\
04(22.2) \\
06(33.3)\end{array}$ \\
\hline $\begin{array}{l}\text { Mean } \mathrm{CD}_{4} \text { count: } \\
\text { cels/dL } \\
\text { (Standard deviation) }\end{array}$ & $\begin{array}{c}400 \\
(+/-375.9)\end{array}$ & $\begin{array}{c}402 \\
(+/-226.2)\end{array}$ \\
\hline $\begin{array}{l}\text { Mean HIV viral load: } \\
\text { copies/dL } \\
\text { (Standard deviation) }\end{array}$ & $\begin{array}{c}9,443 \\
(+/-1,649)\end{array}$ & $\begin{array}{c}99,578 \\
(+/-26,299)\end{array}$ \\
\hline Total & 25 & 18 \\
\hline
\end{tabular}


Male gender was predominant in both groups, $92 \%$ (23/25) in HBV/HIV and 77.8\% (14/18) of the HCV/HIV, and mean age was 37.4 and 39.7 years respectively. Regarding educational level, 24\% (6/25) of the HBV/HIV and 33.4\% (6/18) of the HCV/HIV patients did not complete middle school.

Among HBV/HIV patients, 52\% (13/25) referred multiple sexual partners/year. Two of them had a HBV infected sexual partner and three had a known HIV positive partner. Homosexualism (MSM - men who have sex with men) and bisexualism were present in 28\% (7/25) and 20\% (5/25) respectively. Seven (28\%) patients were adept to condom, but only one of them used it regularly. In the HCV/HIV group $38.8 \%(7 / 18)$ individuals have reported more than one sexual partner/year and $44.4 \%(8 / 18)$ were heterosexual. None of them had a known HCV positive sexual partner and only one referred an HIV positive partner. Two patients referred occasional condom use.

Intravenous drug use (IVDU) was reported by $22.2 \%(4 / 18)$ of the HCV/HIV studied population and in $9.1 \%(2 / 25)$ of the HBV/HIV group. Three patients in each group also referred the use of inhaled cocaine. Alcohol use was present in in both groups: $36 \%(9 / 25)$ of the HBV/HIV group and $44.4 \%$ $(8 / 18)$ of the HVC/HIV one. Only one patient of the HCV/ HIV group had a risky occupation (nursing assistant). There was no history of occupational accident. A tattoo was present in two patients in the HCV/HIV group (11.1\%) and in three $(12 \%) \mathrm{HBV} / \mathrm{HIV}$ co-infected individuals. None of the studied patients were on hemodialysis treatment nor had been submitted to hemotransfusion prior to the co-infection diagnosis.

Only 5/20 HBV/HIV patients had $\mathrm{CD}_{4}<200$ cells/dL compared to $3 / 11$ patients in the HVC/HIV group. The former showed a mean $\mathrm{CD}_{4}$ count of 400 cells/dL (standard deviation +/-375.9; variation: $19-1,607$ cells/dL) and the latter 402 cells/dL (standard deviation +/-226.2; variation: $84-790$ cells/ dL). Mean HIV viral load was one log higher in the latter group: 9,443 copies/mL $(+/-1,649)$ in HBV/HIV individuals and 99,578 (+/-26,299) in the HVC/HIV ones.

\section{DISCUSSION}

In our data, only $52 \%$ and $25.4 \%$ of the newly diagnosed HIV positive patients had known serologic status to HBV and $\mathrm{HCV}$ infection in the first year of medical care. This is of great concern since all these patients are receiving medical attention in an infectious disease reference center. Other studies report the same difficulty in testing patients for hepatitis. Tovo et al. found that only $58.4 \%(343 / 587)$ of the HIV patients on medical follow-up in a tertiary unit in south Brazil were tested for either HBV or HVC serologies ${ }^{(15)}$. Other authors, however, report successful experiences, which leaded to better results. The UK collaborative HIV cohort (UK CHIC) study showed that they were able to gradually increase the proportion of HIV patients tested for HCV over time $(9.2 \%$ in 1996 to $79.9 \%$ in $2007)^{(16)}$. This improvement in screening coverage reflected a change in national management guidelines, since there was a clear instruction that all HIV positive patients should be screened for HCV since at least $2004^{(5)}$.
$\mathrm{HBV} / \mathrm{HIV}$ and HCV/HIV prevalences were $3.7 \%$ and $5.4 \%$ respectively. These are in accordance with other Brazilian published data, in which values ranged from 2.8\%-4.6\% for HBV/HIV co-infection ${ }^{(7,15,19)}$ and $4 \%-6.4 \%$ for HCV/HIV association $^{(6,7,17)}$. Similar to our study, these researches tested HIV patients who were in medical follow-up in infectious disease centers in four distinct Brazilian cities: São Paulo, Porto Alegre, Amazonas and Vitória. However, some authors have found quite different results in studying the prevalence of these co-infections in special populations such as IV drug users $(84.8 \% \mathrm{HCV} / \mathrm{HIV} \text { association })^{(13,14)}$. The mode of HCV transmission could explain this high prevalence.

Co-infected patients were mainly of the male gender in productive age, with a mean age of 37.4 and 39.7 years for HBV and HVC infections respectively. Other studies also reported a higher frequency of these co-infections among men and most of them describe the age interval of $35-40$ years as the most prevalent $t^{(11,15,17,19,20)}$.

A considerable percentage of patients referred to have multiple sexual partner/year. However, bisexualism and homosexualism were more common in the HBV/HIV group. The HBV sexual transmission mode is well documented but the predominance in MSM is not the rule. Although some authors describe the same predominance ${ }^{(12,14)}$, others found different prevalent risk, such as IVDU ${ }^{(18)}$. It is possible that there was a high frequency of MSM in the HIV positive population on follow-up in the studied center, which could explain this result.

Interestingly there was a small frequency of IVDU in the $\mathrm{HCV} / \mathrm{HIV}$ group $(22.2 \%)$. It is possible that the number of IVDU, a key risk factor for this co-infection, is lower in our region than in other Brazilian urban centers ${ }^{(4)}$.

In our study most of the patients were diagnosed coinfected with $\mathrm{CD}_{4}$ counts higher than 200 cells/dL. The small study sample and the presence of missing values possibly caused bias in this result.

The study limitations were the difficulty in collecting reliable data from secondary source (medical records) and the small sample. These could compromise some of the study results. Besides that, some of the study results are of great concern since a low percentage of the HIV infected individual under medical care were tested for viral hepatitis serology in the first year of follow-up, despite the vast literature showing the negative impact of HIV in the HBV and HVC liver disease progression. This reinforces the need for better training healthcare workers and providing laboratory support for a prompt hepatitis infection diagnosis. Routine hepatitis tests are essential for identifying infected people in order to facilitate adequate medical management to avoid complications and to decrease the spread of these diseases. In the same way, the accomplishment of educational programs for the population, providing information about $\mathrm{HVB} / \mathrm{HVC} /$ HIV risk of transmission to others and HBV vaccination, in an effort to reduce viral spread, are very important issue. The study also suggests that larger prevalence studies are necessary for a better understanding of the HBV/HCV/HIV co-infection epidemiology in Ceará. 
Távora LGF, Hyppolito EB, Cruz JNM, Portela NMB, Pereira SM, Veras CM. Soroprevalência da co-infecção hepatite B, C e HIV em um centro no Nordeste do Brazil. Arq Gastroenterol. 2013,50(4):277-80.

RESUMO - Contexto - A ocorrência da associação de HIV com a hepatite por vírus B (HVB) e C (HVC) é preocupante visto que os pacientes coinfectados tendem a ter uma resposta pior à terapia antiviral e uma chance maior de progredirem para a cronificação da doença hepática e suas complicações. No Brasil, os estudos publicados sobre a prevalência dessas coinfecções ainda são escassos e, muitos deles, com resultados conflitantes entre si. Além disso, muitos pacientes coinfectados são portadores assintomáticos dos vírus das hepatites o que causa um atraso no seu diagnóstico, com consequente subnotificação de casos. Objetivos - Este estudo objetiva determinar a prevalência da infecção pelo HVB e HVC em pacientes recém-diagnosticados com HIV no Ceará/Brasil. Métodos - Coorte retrospectivo com pacientes >18 anos, diagnosticados HIV+ de 2008-2010. Foram coletados dados referentes ao primeiro ano de acompanhamento desses pacientes através de revisão de prontuário: fatores de risco para HIV, HBV e HCV e resultados de provas sorológicas para esses vírus. Resultados - Foram acompanhados 1291 pacientes HIV+. Testes sorológicos para HBV foram realizados em 52\% dos casos: $23 \%$ apresentavam hepatite B prévia e 3,7\% eram coinfectados. Apenas $25,4 \%$ tinham testes sorológicos para HCV: $1,5 \%$ tinham hepatite C prévia e 5,4\% eram coinfectados. A maioria dos pacientes HBV/HIV referia ter múltiplos parceiros sexuais em um ano. Homossexualismo e bissexualismo estavam presentes em $28 \%$ e $20 \%$ respectivamente. No grupo HCV/HIV 38,8\% referia múltiplos parceiros sexuais em um ano e o uso de drogas endovenosas ocorreu em $22,2 \%$ dos casos. Conclusão - O estudo reforça a necessidade de um treinamento dos profissionais de saúde e de facilitação do acesso do paciente ao suporte laboratorial para que seja possível o diagnóstico rápido e precoce das hepatites virais, o que levaria a um adequado manejo clínico desses pacientes e a uma redução da disseminação dessas doenças. O estudo sugere também a necessidade de realização de campanhas educacionais para a população, abordando os riscos de transmissão desses vírus e incentivando a vacinação para o HBV, com o intuito de diminuir a propagação dessas doenças.

DESCRITORES - Infecções Oportunistas Relacionadas com a AIDS. Vírus da hepatite B. Hepatite C. Hepatite crônica.

\section{REFERENCES}

1. Bodsworth NJ, Cooper D, Donovan B. The influence of human immunodeficiency vírus type 1 infection on the development of the hepatitis B virus carrier state. $\mathrm{J}$ Infect Dis. 1991;163:1138-40.

2. BRASIL. Ministério da Saúde. Secretaria de Vigilância em Saúde. Departamento de DST, AIDS e Hepatites virais. Boletim epidemiológico - Hepatites virais. Ano III, $n^{0} 1$. Brasília, 2012.

3. Brasil. Ministério da Saúde. Secretaria de Vigilância em Saúde. Programa Nacional de DST/AIDS. Recomendações para terapia antirretroviral em adultos e adolescentes infectados pelo HIV 2007/2008. Brasilia-DF, 2007.

4. Brasil. Presidência da República. Secretaria Nacional de Políticas sobre Drogas. I Levantamento Nacional sobre o uso de Álcool, Tabaco e outras drogas entre universitários das 27 Capitais Brasileiras. Brasília, 2010.

5. Brook MG. Summary of BHIVA guidelines for HIV and hepatitis B or C co-infection. J HIV Therapy. 2003;8:85-8.

6. Carvalho FHP, Coelho MRC, Vilella TAS, Silva JLA, Melo HRL. HIV/HCV [Coinfection at an university hospital in Recife, Brazil]. Rev. Saúde Pública. 2009;43:133-9.

7. Farias N, de Souza I, Coelho DM, de Oliveira UB, Binelli CA. Coinfecção pelos vírus das hepatites $\mathrm{B}$ ou $\mathrm{C}$ e da imunodeficiência adquirida: estudo exploratório no Estado de São Paulo, Brasil, 2007 à 2010. Epidemiol. Serv. Saúde. 2012;21:475-86.

8. Marchesini AM, Prá-Baldi ZP, Mesquita F, Bueno R, Buchalla CM. Hepatites B e C em usuários de drogas injetáveis vivendo com HIV em São Paulo, Brasil. Rev. Saúde Publica. 2007;41:57-63.

9. Paltanin LF, Reiche EM. Seroprevalence of anti-hepatitis C virus antibodies among blood donors, Brazil. Rev de Saúde Pública. 2002;36:393-399.

10. Pereira LM, Marteli CM, Merchán-Harmann E, Montarroyos UR, Braga MC, de Lima ML. Population-based multicentric survey of hepatitis B infection and risk factors differences among three regions in Brazil. Am J Trop Med Hyg. 2009;81:240-7.

11. Portelinha Filho AM, Nascimento CU, Tannouri TN, Troiani C, Ascêncio EL, Bonfim R, D'Andrea LAZ, Prestes-Carneiro LE. Seroprevalence of HBV, HCV and HIV co-infection in selected individuals from state of São Paulo, Brazil. Mem Inst Oswaldo Cruz. 2009;104:960-3.
12. Puoti M, Bruno R, Soriano V, Donato F, Gaeta GB, Quinzan GP, Precone D. Hepatocellular carcinoma in HIV-infected patients: epidemiological features, clinical presentation and outcome. AIDS. 2004;18:2285-93.

13. Rodriguez-Mendez ML, Gonzalez-Quintela A, Aguilera A, Carballo E, Barrio E. Association of HCV and HBV markers in Spanish HIV-seropositive patients in relation to risk practices. Hepatogastroenterology. 2003;50:2093-7.

14. Segurado AC, Braga P, Etzel A, Cardoso MRA. Hepatitis C virus coinfection in a cohort of HIV-infected individuals from Santos, Brazil: seroprevalence and associated factors. AIDS Patient Care and STDs. 2004;18:135-143.

15. Tovo CV, Santos DE, Mattos AZ, Almeida PRL, Mattos AA, Santos BR. Prevalência ambulatorial em um hospital geral de marcadores para hepatites $\mathrm{B}$ e c em pacientes com infecção pelo vírus da Imunodeficiência humana. Arq Gastroenterol. 2006;43:73-6.

16. Turner J, Bansi L, Gilson R, Gazzard B, Walsh J, Pillay D, Orkin C, Phillips A, Easterbrook P, Johnson M, Porter K, Schwenk A, Hill T, Leen C, Anderson J, Fisher M, Sabin C, on behalf of the UK Collaborative HIV Cohort (UK CHIC) Study. The prevalence of hepatitis C virus (HCV) infection in HIV-positive individuals in the UK - trends in HCV testing and the impact of HCV on HIV treatment outcomes. Journal of Viral Hepatitis. 2010;17:569-77.

17. Victoria MB, Victoria FS, Torres KL, Kashima S, Covas DT, Malheiro A. Epidemiology of HIV/HCV coinfection in patients cared for at the Tropical Medicine Foundation of Amazonas. Brazilian Journal of Infectious Diseases. 2010;14:135-40.

18. World Health Organization (WHO). Hepatitis C - 2002. Geneva: Who, 2003. Available from: http://www.who.int/csr/disease/hepatitis/hepc.pdf.

19. Zago AM, Machado TF, Cazarim FL, Miranda AE. Prevalence and risk factors for chronic hepatitis B in HIV patients attended at a sexually transmitted disease clinic in Vitoria, Brazil. The Brazilian Journal of Infectious Diseases. 2007;11 475-8.

20. Zoufaly A, Onyoh EF, Tih PM, Awasom CN, Feldt T. High prevalence of hepatitis $\mathrm{B}$ and syphilis co-infections among HIV patients initiating antiretroviral therapy in the north-west region of Cameroon. International Journal of STD \& AIDS 2012;23:435-8. 